Anniko, M. 276

Azuma, H. 282

Doi, K. 289

Endo, T. 272

Fujisaka, M. 305

Fukushima, K. 282

Furuya, M. 266

Fuse, Y. 289

Hara, H. 259

Hibino, H. 289

Horii, A. 289

Iguchi, F. 272

Ikezono, T. 252

Ishizaki, M. 252

Ito, J. 272

Kakigi, A. 282

Kim, T.-S. 272

Kita, T. 272

Kitahara, T. 289

Kobayashi, K. 305

Kubo, T. 289
Kuramasu, T. 289

Li, L. 252

Masuda, K. 294

Matsushiro, N. 289

Mizukoshi, K. 305

Morita, K. 294

Nakagawa, T. 272

Nishioka, R. 282

Odagiri, K. 300

Ogawa, Y. 266

Onuki, J. 300

Otsuka, K. 266

Pawankar, R. 252

Rokutan, K. 294

Saito, A. 252

Sato, G. 294

Sato, R. 300

Sato, T. 289

Sawada, S. 282

Sekine, K. 294

Shimogori, H. 259
Shindo, S. 252

Shojaku, H. 305

Suzuki, M. 266

Taguchi, T. 282

Takahashi, M. 251, 300

Takeda, N. 294

Takeda, S. 282

Takeda, T. 282

Takeno, K. 259

Takenouchi, T. 266

Takumida, M. 252, 276

Tomiyama, S. 252

Tsubota, M. 305

Wada, R. 300

Watanabe, A. 252

Watanabe, Y. 305

Yagi, T. 252

Yamashita, H. 259

Yasumura, S. 305

\title{
Subject Index Vol. 67, No. 5, 2005
}

Biodegradable hydrogel 272

Calcitonin gene-related peptide 259

Caloric response 266

Canal plugging 266

$\mathrm{COCH}$ gene 252

Cochlin 252

Compound action potentials 266

DFNA9 252

Drug delivery system 272

Endolymph homeostasis, lithium treatment 282

Fluid shift 266

Free radical damage 276

Genetic association study 289
Gentamicin 276

Hair cell 272

Hereditary hearing impairment 252

Immunohistochemistry 252

Inner ear regeneration 272

Isosorbide 276

$K C N E$ gene mutations 289

Ménière's disease 282, 289, 294

- -, epidemiology 305

- $\quad$, stress and prognosis 300

Microarray analysis 294

Nitric oxide 276

Osmotic pump 259

Posterior semicircular canal 266
Potassium channel 289

Sensorineural hearing loss, low tones 300

Single nucleotide polymorphisms 289

Spiral ganglion neuron 272

Stress response 294

Tetrodotoxin 259

Thermoconvective flow 266

Vasopressin-aquaporin 2 system 282

Vertigo attack 294

Vestibular function 259

- organ of rats 252

- sensory cell 276

\section{KARGER}

(c) 2005 S. Karger AG, Basel

Fax +4161306 1234 